\title{
Transparency and Reliability in Financial Statement: Do They Exist? Evidence from Malaysia
}

\author{
Zinatul Iffah Binti Abdullah, Mahmoud Khalid Almsafir, Ayman Abdal-Majeed Al-Smadi \\ Graduate Business, College of Graduate Studies, Universiti Tenaga Nasional, Campus Putrajaya, Kajang, \\ Malaysia \\ Email: zinatul@outlook.com,mahmoud@uniten.edu.my, smadi370@yahoo.com
}

Received 7 August 2015; accepted 24 November 2015; published 27 November 2015

Copyright (C) 2015 by authors and Scientific Research Publishing Inc.

This work is licensed under the Creative Commons Attribution International License (CC BY). http://creativecommons.org/licenses/by/4.0/

(c) (i) Open Access

\section{Abstract}

Purpose: The purpose of this research is to investigate the existence of reliability and transparency in the financial statement, for the benefit of investors and analysts. The scope of the study is to find the relationship of accounting standards, corporate governance, external controls, internal controls, and ethical practices with the financial statements, based on the auditors and management views in Malaysia. Methodology: 52 out of 60 questionnaires were taken from audit firms and management firms to test the visibility of transparency and reliability in financial statements. The qualitative data were also analyzed to understand the financial statements further. Findings: According to the data, the existence of transparency and reliability in financial statements was related with accounting standards, ethical practices, internal controls, external controls, and corporate governance. This finding was supported by many tests through SPSS statistic software. Research Limitations/Implications: The implication that first occurred was the intention of auditors and management in hiding the truths behind transparency and reliability of financial statements. Commonly, audit fees and audit sizes are the main truths that are hidden by the auditors. Practical Limitations: The implications of this were the value of transparency and reliability of financial statements hidden from the investors and its capabilities in restoring those into the financial statement. Originality/Value: The results were put through a quantitative approach. Also, additional qualitative analysis was gathered to attain extra knowledge in the transparency. While the rest of the paper is original, previous authors were also discussed for their theories and hypotheses.

\section{Keywords}

Business Ethics, Transparency, Accounting, Management Accountability, Reliability, Internal 
Controls, Financial Statements, External Controls, Accounting Standards, External Controls, Ethical Practices

\section{Introduction}

Accounting is the process of identifying, measuring, and communicating economic information to permit informed judgments and decisions by users of the information. Hence, a financial statement is a set of accounting that was properly organized into its classification of the income statement; balance sheet; cash flow statement; and statement of equity (Wood \& Sangster, 2008) [1]. These classifications make it easier for the current shareholder and the potential shareholder to analyze the transparency and reliability of the financial statements.

The issue of transparency and reliability in financial statements has been a dilemma, not only for the investors, but also for the business and the accounting industry. The existence of transparency and reliability seems blurred in the business world. That is why this research is investigating the existence of reliability and transparency in the financial statement for the benefits of investors and analysts. Wood \& Sangster (2008) [2] stated that when the relevance, comparability, and understanding were included in the financial statement, the financial statement was capable of relaying information more adequately with the accounting and non-accounting personnel.

The history of transparency has been an issue in the accounting world. Transparency in financial statements has been an issue for years. The collapse of Enron finally opened the eyes of investors and shareholders in seeing the need for transparency. Hence, the investors need to understand the impact that the existence of transparency in financial statements would have in making a decision. The reality is, however, more complicated: The concept of transparency, however, may be manipulated to serve the interests of a few to the exclusion of ethics and to anti-humanism (Bessiere, 2005) [3].

In order to relate with the above title, research objectives were created to understand transparency. The research objectives were to find out how and to what extent the existence of reliability and transparency was in the financial statements for the investor's knowledge and rights. Hence, research questions were made to fulfill these requirements. Those are such as the possibility of ratio as methods, the extent of investors' knowledge, potential variables to the transparency and reliability of the financial statement and to what extent such variables for auditors (internal or external) are highly accepted.

This paper aims to explain the existence of financial statements and the need for various parties to identify the transparency and reliability of financial statements. International Accounting Standards (IAS) 8 [4] explained the accounting policies that should be used by the management. In this case, accounting policies are specific principles, bases, conventions, rules and practices applied by an entity in preparing and presenting financial statements (MASB, 2006) [5]. Also, Wood \& Sangster (2008) [1] believed that the financial statement should provide a true and fair view of the accounting processes which were consistent with the accounting standards and legislation.

The duration of this study occurred from June until August 2012. However, the study falls under a cross-sectional study which means that it was completed within one period only.

\section{Literature Review}

Around the world there are many debates about transparency and reliability of the financial statements since the collapse of Enron and other companies. The companies have been damaging the purpose of the financial statements. Furthermore, the investors no longer trusted the financial statement for decision-making needs. Hence, it implies the possibility of the existence of transparency and reliability on the financial statements. Thus, this paper shall discuss various matters that may or may not affect the transparency based on previous studies.

\subsection{Financial Statements}

Bessire (2005) [3] argued whether transparency is a two way mirror or a one way mirror. The truth is that transparency is a two-way mirror. To be able to see the inside of the organizations, transparency had revealed the inside and outside of the financial statements. However, there are many limitations on making transparency a twoway mirror. However, the author agreed that financial statements should be a two-way mirror, although it is 
something impossible to achieve in the current world. Since financial statements revealed the inside operation of the organizations, it reflected the outside participants such as stakeholders and shareholders as well. The author agreed with Damodaran (2007) [6] and found that the ways to ensure the transparency of information are based on the corporate disclosures in the statements. Most companies did not include precious information which ended up making the investors decide wrongly for their investments. Sometimes, it misled the investors. Hence, this author unravels the reasons and the ways to evaluate transparency and reliability of the information in the financial statements.

According to Berggren \& Bernshteyn (2007) [7], transparency is vital to drive the company performance when such transparencies are practiced to enhance employee contributions. It is common that transparency ensures less extra work that occurs after the financial statements were published. It actually motivated the employees to work better and strive for the future of the organizations. Hence, it relates to corporate disclosures as stated by many authors above. This opinion is similar to Crumpton (2011) [8] and revealed that transparency has a high value in the business world. The value of transparency is well-explained in the above transparency nodes; transparency nodes such as Organizational transparency drives company performance and Information transparency and valuation: “Can you value what you cannot see?” However, it does relate to the ratios and the models from other authors and topics listed in this literature reviews for the transparency and reliability in financial statements.

In this case, it is almost similar to the concept transparency from Jamshidinavid, Chavoshani \& Maroofi (2012) [9]. The authors were using questionnaires to understand how web accounting can damage transparency or enhance transparency. As CIMB won the best transparency in 2011, their annual reports are posted online instead of as a book annual report. This research found that web based accounting can increase the qualitative norm of relevance, and increase the reliability of the financial statements, which can be used for decision making processes. In the other case, arguments over financial reporting transparency and earning management to have a relationship found the result in the experiment (Hunton, Libby \& Mazza, 2004) [10]. The findings revealed that it can affect transparency in selective sales of securities and the ways such securities of sales needs to be recorded in the financial statement.

As CIMB won the best transparency in 2011, their annual reports are posted online instead of book annual report. This research found that web based accounting increase the relevance and reliability of the financial statements which beneficial for decision-making processes.

\subsection{Accounting Standards}

In the other case, Vrentzou (2011) [11] revealed the accounting standards that should be followed to minimize any fraudulent activities. Fraud occurs because the companies tend to use different accounting methods that were successful for other business industries. Hence, a good knowledge of International Financial Reporting Standards (Worldwide), Financial Reporting Standards (under MASB Malaysia), Sarbanes Oxley Acts and Organizational for Economic Co-operation and Development are required in enhancing the transparency and reliability of financial statements. Abdolmohammadi (2005) [12] revealed that the intellectual capital and market capitalizations are some issues that cannot be determined by the naked eye. He found that there are some levels of disclosure on this matter in the financial statements made by various public companies, and found a positive result. In this case, it is defined that such transparency occurs in recording intellectual capital and market capitalizations.

Liguori \& Steccolini (2011) [13] stated that accounting change occurs when a particular type of accounting can no longer support the organizations. For example, changes in the estimated (FRS) or changes in the goodwill are estimated. The author decided to brief more about the accounting change for a better understanding in interpreting the outcomes in the financial statements. In this case, Weetman (2003) [14] stated that the needs of FRS 3 as a total recording of financial statement were vital or not vital to the organizations. She revealed that users of financial statements favored the accounting standard board as it is concerned on stock market. The accounting standard board served the interests of users of the financial statement well. It is wiser to request the reason as to why the accounting standard board choose FRS 3 as the standards for critical matters. Again, she revealed that the participants in the survey, has established control of the standard-setting agenda and acted on the role of the regulator.

Sevin, Schroeder \& Bhamornsiri (2007) [15] conducted a quantitative test investigate whether disclosure ap- 
pears to be a function of the materiality of the spending. Using statistical tests, including multiple regressions, the authors were able to differentiate the use of voluntary disclosure theory and legitimacy theory. In this case, Cho, Freedman \& Patten (2012) [16] decided to use several mixtures of the theories to report the transparency of the corporate disclosure to support those theories of Sevin et al. (2007) [15]. Some companies only reported minimum disclosure matter that lead to various suspicions and confusion. Hence, ratio has been known to reveal the truth in the transparency by calculating the specific ratio on the cash-flow statement, income statement and balance sheet. Thus, the investors shall find the truth about the well-being of the organizations.

\subsection{Corporate Governance}

Yakhou \& Dorweiler (2004) [17] agreed with Rezaee (2004) [18] that accounting and corporate governance can restore the public trusts towards the financial statements and the accounting professions in the world. Accounting standards and corporate governance are ethical principal practices to ensure the reliability and transparency of the financial statements. Corporate governance covers not only the principal (shareholders) and the agent (directors), and its employees. Rezaee (2004) [18] stated that ethical practices and additional requirements are necessary to ensure that the auditors serve their duties right to unraveled the fraudulent matters in the financial statements. Also, it can identify the extra needs to follow other standards and principles to support the transparency and reliability in the financial statements. Hence, it can prove the existence of transparency and reliability in the financial statements.

Skaifea, Collins and LaFond (2006) [19] revealed that the firm credit rating is unrelated to the number of block-holders in the company. However, the firm credit ratings have positive results on the weak practices of shareholder's rights during the AGM or EGM. The statistical data that was collected managed to reveal the truth of firm credit ratings and shareholder's right in the organizations. However, it has high positivity with the degree of transparency in the organizations. This article is related to Atkinson (2002) [20], Adams (2004) [21], Stone (2003) [22], Yakhou, and Dorweiler (2004) [17]. Brennan and Solomon (2008) [23] have taken their data to compute the references about accountability and presenting a framework on corporate governance. It is the best way to enhance transparency because corporate governance is known as the umbrella to the shareholders and organizations. Certain methods have been found to reveal transparency and accountability from the financial statement effectively.

Grant (2001) [24] was researching about corporate governance and its effectiveness in the accounting worlds. The researcher wanted to understand the history of corporate governance and the events that relates to failure in aligning the interests of management and shareholders. This author agreed with Yakhou \& Dorweiler (2004) [17] about the management and shareholders' interests. However, he recommended that the corporate governance combined with Sarbanes-Oxley Act to increase the responsibility of managements towards the shareholders and external parties. It is supported by this article. Rezaee, Olibe \& Minmier (2003) [25] revealed the result that the audit committee has a responsibility towards the corporate governance act, internal controls functions (in term of financial reporting, structure and audit functions), and external audit activities. Hence, the authors stated that internal auditors need to adopt a formal written report consisting of their responsibilities, their composition, their structure and qualifications, and be required to be reviewed and revised at least once every three years. This is done to increase the accountability towards the shareholders (principal) and the external parties.

\subsection{Internal Controls}

Stone (2011) [22] is more concerned with the lack of communication skills between the management and the accountant in the organizations. It is because both parties do not communicate jointly for the organizations. The accountant was previously not given higher priority but now, it is one of the top positions the company needs to fill. Hence, face-to-face is preferred in explaining and understanding the goals, the objectives and the paths of the organizations. It is supported by the next article. Spira \& Page (2003) [26] conducted research on transferring internal control into the risk management process. The observation showed that risk management becomes aligned with internal control once it flows with corporate governance policy. Thus, the risks are manageable and turned into accountability for the function and financial statements. These authors agreed with Jamshidinavid, Chavoshani \& Maroofi (2012) [9].

Liou (2008) [27] argues that the investors need to know other methods besides ratio in determining the financial statements. The article is smart enough to use ratio in detecting fraudulent or misstatement in the financial statements. In addition, the author decided to add some models to add extra cautious on the calculation which 
enhances the transparency and reliability on the financial statements. In this case, it supported Kaminski, Wetzel \& Guan (2004) [28] where they revealed the use of ratios in determining the transparency and reliability of the information in the financial. This article actually suitable to be combined with Liou [27] article titled: Fraudulent financial reporting detection and business Failure prediction models: a comparison. Both are talking about using ratio to make the analysis in order to detect fraudulent in financial reporting.

Hyland \& Verreault (2003) [29] conducted a survey on one of the CPA firms. They revealed that value creating combinations occurs when they combined the frameworks for Internal Auditing and Human Resource Management. This is best to aligning their relationship, the benefit of self and peer-appraisal implications of their locations and enhances the value-creating quadrant (ex. Motivation). These value-creating combinations are capable to draw positive results on several research questions especially working relationship and audit planning process on the strategic HRM. It means that the next article supported Hyland \& Verreault [29]. Morrill \& Morrill (2003) [30] suggested that audit-specific knowledge, experiences and expertise are important factors of internal audit participation. It occurs when a company requires such higher levels of expertise due to their nature of their business in the industry. The expertise creates greater efficiencies by promoting the internal auditors' participation in the external audits results as well as lowering the costs of external audits for extra effectiveness on auditors' reports.

\subsection{External Controls}

Jr \& Zhou (2006) [31] revealed that greater results and effectiveness in preliminary evidence occurred when the audit committee alignment has been flows together with SOX and securities exchange requirements. It means that combinations of these Acts increases the quality of the financial statements and the auditors' reports in the eyes of shareholders and external parties. It is important to follow such Acts if the effects are greater towards the financial statements in term of its reliability and transparency. Thus, Al-Ajmi (2009) [32] has revealed that bigger auditing firm provides more quality compared to the smaller firms. It means that there is more independence for the bigger firms to audit statement their client's financial statements. Hence, it supported that the auditor report is not only to enhance the financial statement, but to increase the reliability and the transparency of the information.

Clavel, Martinez \& Ortiz (2003) [33] found that there are differences between net income and shareholders' funds preparation according to domestic GAAP and US GAAPs. Also, it was identified differently in the industry itself. All these options are only a matter of simple ideas when IAS (International Accounting Standards) needs to be handling for proper financial statement preparations. Bierstaker (2003) [34] conducted an experiment on the auditors based on their training sessions and found that there are differences in the results. Auditors with lower levels of internal controls are experienced in part-list interferences, however internal control evaluation of auditors are not affected by the flowcharts due to their high levels of internal control knowledge. It is because the flowcharts are the guidelines for their auditing processes to the ends results. In the case of accounting procedures, auditors' recalls were found significant as it was not that important for them.

Suwaidan \& Qasim (2010) [35] revealed that external auditors in Jordan heavily relied on objectivity, competence and work performance of their internal auditors. Hence, these affected their reliance decisions on the auditing matter. Also, the size of external auditors company was the best way to explain the estimated fees relating to auditing processes per year for all the companies. However, the authors decided that there was no relationship between reliance of external auditor on internal auditor and external audit fees. Haron, Chambers, Ramsi \& Ismail (2004) [36] disagreed with Suwaidan \& Qasim (2010) [35]. They founds that the company policy maker should focus on the development and criteria when they selected the internal auditors to enhance the importance of competence and work performed of the internal auditors. When such criteria has been developed and trusted, only the external auditor would rely more on the internal auditors' report which reduces the cost of external audits for the companies.

\subsection{Ethical Practices}

Atkinson (2002) [20] is actually backing up the facts provided by previous researchers. He stated that controls can improve the quality of financial reporting. He conducted a study on various universities offering accounting courses whether ethics and communication subjects are taught in the courses. It means transparency and reliability can be found in the financial statements when this is applied. While, Stone (2003) [22] believes that commu- 
nication is vital between accountant and managers, communication is vital for the accountant to external auditors in order to increase reliability and transparency of the data. Adams (2004) [21] actually agreed with Atkinson [20] for the ethical practices, ethical issues and ethical conducts. In this case, the accountant and the auditor need to be very ethical in their reporting of financial statements. Hence, the gaps will enhance the transparency of those important matters that should be taken into account and published for the right of the public in the market.

Thurasingam \& Sivanandan (2012) [37] conducted a questionnaire to test the drive of generation Y's towards law and ethics. Well, the researchers found that generation $\mathrm{Y}$ were not driven by any differences in gender, race and religion. However, they may be influenced through moral reasoning, age, educational background, parents, peers, social upbringing, ethical knowledge and socioeconomic status. It means that their ethical conducts are based on their self-reasoning of such consequences. It is the opposite of Makkawi and Shick (2003) [38]. They conducted a survey in CPA form, involving 70 senior auditors. The test was to identify whether auditors have high or low sensitivity towards fraud. According to the results, the auditors were required to audit smarter. It is because the auditors were under fixed fee environment and yet, they were required to balance between effectiveness and efficiency of audits' reports. The authors suggested that extra training would be able to cope with the fee environments and audit smarter for specific company’s industry and environment.

Jackson \& Lapsley (2003) [39] revealed that accounting techniques are normally used at official bodies. Hence, accounting change can cause frustration and confusion. Those frustrations occurred when they are forced by regulations, statute or accounting standard boards of the country. However, the respondents have reported independent innovation of accountant techniques because the companies are under pressure to improve their efficiency of operations and transparency of financial statements. In the other case, Shapeero, Koh \& Killough (2003) [40] found that accountants have a different view on premature sign-off from underreporting activities. In this case, the respondents believe in rewards more than any premature sign-off activities. The authors suggested that some accountants may use consequences-based approach when they want to decides for any ethical content as it has high consequences in the accounting world.

\section{Methodology}

\subsection{Introduction}

The research has taken a mixed method by using both a quantitative and a qualitative approach. Firstly, the research is conducted through a questionnaire using five-likert scale and analysis approach. This questionnaire has been sent to the respondents for their responses towards the factors on transparency and reliability of the financial statements. The respondents totaled 60 people, 30 samples from auditor's firms, and 30 samples from management firms. The questionnaires were asking questions about ethical standards, accounting standards, corporate governance, internal control and external control for the financial statements. Hence, these questionnaires were gathered from the previous studies that mentioned in the literature reviews. To achieve the aims of this study, the researcher has developed the below hypotheses:

$\mathrm{H}_{0}$ : There is no significant relationship between financial statements with the independent variables.

$\mathrm{H}_{1}$ : There are transparency and reliability in financial statement through the proper knowledge of accounting standards.

$\mathrm{H}_{2}$ : There are transparency and reliability in financial statement through the acceptance of corporate governance policy.

$\mathrm{H}_{3}$ : There are transparency and reliability in financial statement through the improvement of internal control functions.

$\mathrm{H}_{4}$ : There are transparency and reliability in financial statement through the enforcement made by the external parties such as shareholders; securities exchange commission and external auditors.

$\mathrm{H}_{5}$ : There are transparency and reliability in financial statement through ethical practices and conducts while reporting the financial statements.

$\mathrm{H}_{6}$ : There are transparency and reliability in financial statement through combination of accounting standards, corporate governance practices, internal control functions, external control enforcement and ethical conducts and practices in the organizations.

\subsection{Reliability Analysis}

Good results from the questionnaires obtained if there is a reliability instilled within the questions and variables. 
Reliability means other research can trust the data and information. Hence, it is correct. In this case, Cronbach's Alpha can increase the reliability of the data and results. As the Table 1, it shows the data of each variable and Cronbach Alpha in determining the reliability of the data. The Cronbach Alpha for all variables includes here.

\subsection{Data Collection}

Structured questionnaires were constructed to collect the point of views from the managements and auditors. 60 questionnaires were released to the respondents by email, by internet and by hand. All 60 questionnaires were returned for the analysis process. Only 52 questionnaires were potentially available for analysis for both qualitative and quantitative. The response rate was $85 \%$.

\section{Results}

\subsection{Descriptive Analysis}

When the data recorded into the system, SPSS revealed that $50.9 \%$ of the respondents were female while $49.1 \%$ of the respondents were male that are from $84.9 \%$ from Malaysian and $15.1 \%$ respondents were non-Malaysian. To understand well about the topic, about $56.6 \%$ of the employees from management field and $43.4 \%$ of auditors with degree about $56.6 \%$ and ACCA or professional certificates about $24.5 \%$ have answered the questionnaires. Other than that, the respondents' education level for diploma was $1.9 \%$, and Master was $17.0 \%$ of the total frequency. As for age, the frequency of age was 27 - 31 years with $47.2 \%$ that means the results were reliable and authentic from the experience employees. Next, 26.4\% of respondents were aged about 22 - 26 years, 17.0\% for 37 - 41 years, 31 - 36 years (1.9\%), 42 - 46 years (1.9\%), 47 - 51 years (1.9\%), and 52 - 56 years (1.9\%). Hence, it was supported with $56.6 \%$ and $43.4 \%$ who were holding senior positions and junior positions either in management or auditing fields.

\subsection{Normality Distribution Test}

This research used the method of skewness and kurtosis statistic in accessing the normality of data taken from the respondents.

As shown in the Table 2, the researcher found that the normality between all the variables were far from the normal ranges used in the methodology. The data should conclude for skewness is range at +1 and -1 as well as kurtosis is range between +1 and -1 . In the Table 3 , it shows the results of skewness and kurtosis within the agreed range of +1 and -1 .

\subsection{Regression}

According to the Table 4, a summary of the regression showed that there is a valid linear correlation between the dependent and independent variable. It found through $\mathrm{R} . \mathrm{R}$ is 0.603 constantly within the variables:

$$
F S=-20.144+1.138 A C-0.290 I C+4.006 E C+1.332 E P-2.476 C G+e .
$$

The estimated of $\mathrm{R}^{2}$ is 0.355 which means about $35.5 \%$. The variance of dependence variable explained in the variance of independent variable. The $\mathrm{F}$ is 5.175 is substantiated at the $1 \%$ significance level because the

Table 1. Reliability.

\begin{tabular}{ccc}
\hline Variables & Cronbach's Alpha & Number of Items \\
\hline Financial Statements & 0.862 & 6 \\
Accounting Standards & 0.895 & 6 \\
Corporate Governance & 0.937 & 6 \\
Internal Controls & 0.893 & 6 \\
Ethical Practices & 0.912 & 6 \\
External Controls & 0.919 & 6 \\
\hline
\end{tabular}


Table 2. Normality.

\begin{tabular}{ccccccc}
\hline & \multicolumn{3}{c}{ Cases } \\
& \multicolumn{2}{c}{ Missing } & \multicolumn{2}{c}{ Total } \\
\cline { 2 - 7 } & $\mathrm{N}$ & Percent & $\mathrm{N}$ & $\mathrm{Percent}$ & $\mathrm{N}$ & Percent \\
\hline Total FS1 & 52 & $100.0 \%$ & 0 & $0.0 \%$ & 52 & $100.0 \%$ \\
Total AC1 & 52 & $100.0 \%$ & 0 & $0.0 \%$ & 52 & $100.0 \%$ \\
Total CG1 & 52 & $100.0 \%$ & 0 & $0.0 \%$ & 52 & $100.0 \%$ \\
Total IC1 & 52 & $100.0 \%$ & 0 & $0.0 \%$ & 52 & $100.0 \%$ \\
Total EP1 & 52 & $100.0 \%$ & 0 & $0.0 \%$ & 52 & $100.0 \%$ \\
Total EC1 & 52 & $100.0 \%$ & 0 & $0.0 \%$ & 52 & $100.0 \%$ \\
\hline
\end{tabular}

Table 3. Skewness and kurtosis.

\begin{tabular}{ccc}
\hline & Skewness & Kurtosis \\
\hline Total FS & -0.458 & -0.816 \\
Total AC & 0.307 & -0.002 \\
Total IC & 0.045 & -0.934 \\
Total EP & 0.575 & -0.900 \\
Total EC & 0.506 & -0.577 \\
Total CG & 0.296 & -0.891 \\
\hline
\end{tabular}

Table 4. Regression.

\begin{tabular}{cccccc} 
Model & $\mathrm{R}$ & R Square & Adjusted R Square & Std. Error of the Estimate & Sig. \\
1 & $0.601^{\mathrm{a}}$ & 0.361 & 0.291 & 4.30321 & $0.01^{\mathrm{a}}$ \\
\hline
\end{tabular}

${ }^{a}$ Predictors: (Constant), Total EC, Total CG, Total AC, Total EP, Total IC, Dependent variable.

$p$-value is $<0.01$. Thus, the null hypothesis was rejected since it is $p<0.027$. In this case, the researchers discussed which hypotheses won the case for the relationship with the financial statement.

According to the linear regression, the hypothesis 1 can be accepted because the sig level is 0.484 . In this case, there is a transparency and reliability in financial statement through the proper knowledge of accounting standards.

Second, hypothesis 2 tested on the transparency and reliability in the financial statement through the acceptance of corporate governance policy. The results for sig level are 0.828 which resulted to acceptance of this matter. Third, it is the hypothesis 3 through improvements of internal controls function. The sig level is 0.208. Hence, the researcher believes that a small improvement of internal controls functions might be beneficial for transparency in financial statements.

Fourth, it revealed that the sig level for hypothesis 4 is 0.332 . It means there are slightly results than the financial statements transparencies gathered with full support and controls from the external parties such as auditors, shareholders, and securities exchange commission and public. Fifth, the hypothesis that tested the transparency and reliability through ethical practices resulted in 0.368 . As a single detail, the researcher decided to accept that the employees need to conduct ethical practices to ensure that fraud, bribery and misstatements would not occur in the business.

In conclusion, it is easier to say that the researcher picked the entire hypothesis and confirmed that hypothesis 6 is more suitable for the declaration in this research. It means there is transparency and reliability in financial statement through combination of accounting standards, corporate governance practices, internal control functions, external control enforcement and ethical conducts and practices in the organizations. 


\subsection{Multi-Collinearity Analysis}

Checking multicollinearity was vital because the researcher can check the correlation coefficient between financial statements, accounting standards, ethical practices, internal controls, external controls and corporate governance. Multicollinearity existed when the correlation coefficients are high between the variables. According to Table 5, the Pearson correlations are 0.326 between financial statements and accounting standards, 0.472 with corporate governance, 0.0514 towards internal controls, 0.563 together with ethical practices and 0.542 with external controls.

In this time, only p value for accounting standard is more than 0.01 . However, $\mathrm{p}$ value for accounting standard is not more than 0.05 . Hence, the accounting standards is still accepted, and null hypothesis again was rejected in this case. Thus, it explained the same conclusions in the regressions that all independent variables played a role in the transparency and reliability of the financial statements towards various parties that used the financial statements for investment evaluations.

\subsection{Analysis of Qualitative Questionnaires}

A simple analysis of eight questions has been conducted to the auditors and the management to understand the questionnaires. It is necessary to understand each part that was vital to be understood by the external parties on why and how transparencies and reliability of financial statements could occur. 48 parties agreed that transparency and reliability is necessary for the investors. Two participants mentioned that transparency and reliability are both vital for the investors. It is because they (the businessman and individuals) are making initial investments to the companies. Also, another participant replied that the investors are investing their trusts and money into a corporation. Hence, the financial statements should be reliable and transparent to prove their faith and trusts on their investments. Despite that, four members disagreed with the statement that transparency and reliability is vital to the investors. One participant commented that as an investor, financial statements should only present some part of the truth in the organizations. As long as they can understand the financial statement, it should be enough for them. However, the researchers believe that transparency and reliability is critical for the investors.

The second questions asked about the possibility of reliability in the financial statement (current or past) for decision-making processes. Only 37 participants agreed with this statement. Another 15 disagreed that financial statements are reliable enough for decision making. Two participants who agreed with the statement stated that financial statements are reliable enough for decision making. It is because the audited financial statement checked by the external auditors and security and exchange commission. Hence, it is reliable due to the external auditors. Other participants explained that the income statements show the business's gross profit margin and the profitability of the company. Hence, it shows transparency and reliability of the financial statements when all the ratios prove good percentages in calculation. However, the three participants who commented and disagreed with the questions above stated that not all financial statements are reliable for decision-making processes. Last he heard, some corporations are hiding the truths of the operations of the companies. When it occurs, the reliability has been damaged and fully no use for decision-making processes for the current time or the future.

Table 5. Colliearity.

\begin{tabular}{|c|c|c|c|c|c|c|c|c|}
\hline \multicolumn{9}{|c|}{ Coefficients $^{\mathrm{a}}$} \\
\hline & \multirow{2}{*}{ Model } & \multicolumn{2}{|c|}{ Unstandardized Coefficients } & \multirow{2}{*}{$\begin{array}{c}\text { Standardized Coefficients } \\
\text { Beta }\end{array}$} & \multirow{2}{*}{$\mathrm{t}$} & \multirow{2}{*}{ Sig. } & \multicolumn{2}{|c|}{ Collinearity Statistics } \\
\hline & & B & Std. Error & & & & Pearson & Sig \\
\hline \multirow{6}{*}{1} & (Constant) & 11.200 & 4.911 & & 2.280 & 0.027 & & \\
\hline & Total AC & -0.182 & 0.257 & -0.112 & -0.706 & 0.484 & 0.326 & 0.019 \\
\hline & Total CG & 0.178 & 0.813 & 0.041 & 0.219 & 0.828 & 0.472 & 0.000 \\
\hline & Total IC & 1.181 & 0.925 & 0.240 & 1.276 & 0.208 & 0.514 & 0.000 \\
\hline & Total EP & 1.022 & 1.042 & 0.244 & 0.980 & 0.332 & 0.583 & 0.000 \\
\hline & Total EC & 0.938 & 1.031 & 0.216 & 0.910 & 0.368 & 0.542 & 0.000 \\
\hline
\end{tabular}

${ }^{\mathrm{a} D e p e n d e n t ~ V a r i a b l e: ~ t o t a l f s . ~}$ 
The third questions deal about the reliability of financial statements once it audited by the auditors. 38 participants agreed that the financial statements audited by the auditors are reliable. Here are some of their comments. One participant stated that the auditors are professionals. They have their audit procedures to investigate those items in the financial statements and audit programs to ensure that audit procedures done efficiently and thoroughly. Other participant said that the payments to auditors added reliability to the financial statements. Others, 14 members against with the statement regarding payments to auditors added reliability to the financial statements. They disagreed that audited financial statements are reliable. One participant told that external auditors will never release unqualified audit reports. It means the reliability and transparency fall under the management's job. The auditors were only inspecting the truth, however the truth recorded by the employees of the companies. Also, three members said that they do not believe on the financial statement before or after it has been audited by the auditors.

Fourth, the researchers wish to know the reasons why a company did not practice transparency in their financial statements. Many participants only answered yes or no. However, several members contribute set of ideas on the reasons behind lack of transparency in the financial statements. Firstly, it is because the operations are enormous, and the employees lack enough time to produce truths in the financial statements for the external auditors. Second, it is because of lack of time. Hence, they decided to hide the truths from the competitors. It is to avoid the competitors to follow some methods of ways or processes the companies produced their products. Third, it is the intentions of management to cheat the investors, tax committee and stakeholders. It is usually done to reduce the tax to be paid by the companies. Fourth, the companies already gathered enough funds for the business. Hence, they neglected the transparency in the financial statements as their business goals. Fifth, the companies said that they cannot reveal their secrets to their competitors. The companies believe that it is better to shield them than revealing transparency and truths instead. Sixth, the management wishes to cut the costs. They felt that ensuring such transparency and reliability are costly for the companies to bear. Also, it means that the threats exposed to the competitors. Thus, the management believes that transparency and reliability can damage the well-being of the companies.

The fifth questions asked whether every business practice transparency in their financial statements. 35 participants agreed that every business should practice transparency in their financial statements. Three participants were saying that it depends on the companies and usage of such transparency in their financial statements. The rests said that they disagreed with such statements. Let's take a look at their comments. The reasons why every company should practice transparency in the financial statement is because the benefits for the investors. It is either the investors for the company who wants to invest their money to other companies. It is beneficial for the individual's investors. Since this participant likes to invest money, he believes that the transparency should include in the financial statements. Another participant encouraged every business practice transparency in their financial statements. In the other case, the participant stated that the transparency depend on the capitals needed by the company. When a company needs extra capitals, they need to ensure transparency and reliability included in the financial statements.

The researcher began to wonder whether corporate governance enhanced the reliability and transparency in the financial statements. How about the increases of internal control? In this case, the researchers separated the questions into two types of questions. 40 participants voted that corporate governance enhance the reliability and transparency in the financial statements. Five participants agreed with the comments that corporate governance enhanced a part of the reliability and transparency in the financial statements. Then, additional improvements from internal control functions shall enhances full transparency and reliability status of the financial statements. In this case, corporate governance is considered like a vitamin for the businesses and investors. It is a compulsory vitamin for the investors. When it is include together with Sarbanes-Oxley acts and internal controls, it is like a vitamin to work well inside and outside the companies. In the other case, 50 participants agreed that the companies should increase their internal control functions. The participants showed that the companies should begin their improvements on their internal controls functions. It is crucial for the transparency and reliability when included in the financial statements. Also, internal controls are vital for the transparency and reliability of the financial statements. It is done to avoid fraud, misstatements and bribery cases that occurred in the organizations.

In the end, the researchers wanted to know the opinions of the participants, either they are under managements and auditors about CIMB Bank. CIMB Bank declared their efforts were showing transparency and reliability in the financial statements. It created reliability to the whole financial statements which are good for the 
investors and managements in the future. Only 25 participants agreed with this statement. Most of the participants from management background dislike this idea of transparency in the financial statements of CIMB Bank. One participant said that this is the best bank in the world. Other participant congratulated CIMB bank for being the best company who managed to increase the transparency and reliability of the financial statements. It is similar to the third participants who stated that he amazed with CIMB actions. She mentioned that CIMB Bank might be the number one bank who added transparency in the financial statements. It agrees with the fourth participants who said that CIMB Bank is doing very well for their customers and investor's rights. Lastly, the other participants revealed that CIMB will be able to attract more investors to invest their money into the business. Hence, it should unleash more profitability for the bank. Thus, they can show the other banks and companies the importance of transparency and reliability in the financial statements.

\section{Expected Significant Contribution to New Knowledge/Expected Benefits to the Country/Society/Organizations}

\subsection{Country}

\subsubsection{Positive Significant}

a) Increase the cash flow for the country

According to the auditors, transparency in financial statements helped to increase the cash-flow of a country. This question might be ambiguous, however the answer fits right. The auditors believe that more investors will spend their money investing in their preferred company. They might not choose one company but multi-company to invest their stock. When they gained the income or profit from the investment, they will use it to invest again in the same company and other companies. Hence, the cash-flow for a country are working well and contributed to success in many ways. That's why transparency in the financial statement contributed in large number of benefits to the country.

b) Reduce unemployment rate

In the case of unemployment rate, it is obvious that transparency and reliability in financial statement contributed in it. The reasons are simple. When investors keep investing money into an organization, many opportunities for employment arises. When investors gained profits from their investment, they are happy to contribute large amount for it. Hence, more projects and work opportunities are open for the public. It allows the unemployed to be employed in an organization.

c) Create better financial

Transparency and reliability in the statement created better financial for the country. Yes, it is true. When trusts are developed between two parties, it generated income and profits. Those income and profits are giving to many parties for their spending either in investment, projects or shopping. Normal employees spend for clothes and bags which increase financial power and cash flow in the country. Top management might spend on redevelop or bid for more projects to increase the company financial power. Investor helped the management increase their financial power to gained projects, investments or branches.

\subsubsection{Negative Significant}

a) Increase unemployment rate

When transparency and reliability in the financial statement are questioned, it causes many troubles to many parties. It does not only affect the top management but it affected every single person in an organization. It included the cleaners and drivers that were appointed to work with the organizations. How does this happen? When the investor withdraws their investment to other parties, it might increase employment rate because many people were removed from their position. It is because the stocks are returned to the company or sell to another party at much lower rate. Hence, the company cannot bid or proceed with many projects in their hands. Rather, they might be able to concentrate on one or two projects with a large reductions on the employees in the organizations.

\subsection{Society}

\subsubsection{Positive Significant}

\section{a) Trusts/Cooperation}

The word trust is dangerous in the investor's world. It is because people can hardly can trust the organization. 
Companies set their trusts to employees that increase their motivation to contribute in the company's projects or investments. That's how transparency and reliability in the financial statement is set for the investors. The investor's trust is not something to be taken lightly. As many laws have been set, the shareholders have power to take down a company that they find suspicious. Many investors took the lesson of accounting to measure the accuracy of an organization's financial statement. With trust, they invested a large amount of money to an organization. It helped to increase financial power of an organization to conduct their day-to-day activities.

b) Communication

Communication is vital in the world of transparency. Yes, only communication helped transparency occur. The accountant can speak with oath in front of the investors if the investors have doubt about the financial statement. The directors need to explain everything to the investors. They must be willing to answer any question raised during annual general meetings. They must try to be patient to conduct the meetings and to attend to every inquiry of the investors. It is because investors can lead to other investors that would invest in the organization. Hence, more numbers of investors would help to increase financial power of the organizations.

\subsubsection{Negative Significant}

\section{a) Mental Breakdown/Anger}

Investors are not someone anyone can play with. They invested large amount of money to a corporation. They have the right to sell or buy or withdraw the stocks from an organization. Withdrawal reduces the financial power of an organization. When an investor feels they can't trust an organization, they will fall into two types of negative investors. Normally, mental breakdown or anger happens when the investors loses a significant amount of investment from the corporation. For example, stock markets purchased are US 5.91 but stock markets are currently US 1.91. These causes mental breakdown or anger in an investor. This power allows the investors to dig deeper at reasons as to why and how such a problem occurred. It reduces the trust and cooperation, yet increases suspicion and rumors.

b) Wasting Time/Investment

Many investors are still afraid to invest in a particular corporation. It is especially a corporation sold to other parties or a corporation with a bad image previously. Any rumors can plump the stock market price. Hence, it increases suspicions and anger in investors. They have been investing for years to see the development of corporations. They wanted to see the profits and gain for the benefits of their investment. Hence, a corporation that increases these matters should try to make the investor's happy. It is because the investors has power to change chief executives and directors in their corporation. They might even tell other investors or main agents about the truth of this organization. Again, image are destroyed when such truth are released in the market.

\subsection{Organizations}

\subsubsection{Positive Significant}

\section{a) Respect/Trusts}

Once the investors withdraw all the investments from organizations, the amount of stock price will plump easily. It means danger because not much investors love to invest in a company with low stock market. It shows that the company is not doing well. There might be an investor who buys those shares at low prices. They will not withdraw their investment largely or one shot but rather they choose another option that will not depressed their organizations. Transparency and reliability in financial statement helped to retain the current shareholders well because the trusts are instilled in them. It means they will take things slowly to monitor compared to taking out investments in one direct way.

b) Image Management

What can transparency and reliability of a financial statement do with image management? It means a lot to an organization. Only investors can relate to the image management of a company. An investor released a word about the organization. If it is positive, the image of the company increases in a large number. It helped to gained more projects and more collaboration between countries or companies. Malaysia has a system that allows investors from other countries to invest in their preferred organizations. They have power to overrule any organization because they have basic knowledge or accounting knowledge based on the history of Enron and other companies. Also, they have the ability to talk to other parties from separate corporations in other countries or similar countries to invest in this particular company. It increases the stock markets, employment rate and image of the corporation. This is known as free image management created by the investor. 


\subsubsection{Negative Significant}

\section{a) Liquidations/Bankruptcy}

When the investors detect that the financial statements are not transparent and not reliable, big troubles arises for the organizations. It is not one big trouble but many types of troubles that may occur to bring down an organization. At this moment, the investors can request the court to validate the company wellbeing. Then, they may ask for liquidation or bankruptcy. Bankruptcy does not happen because a company requested it. In today's world, a group of investors can request bankruptcy for suspicious company. Liquidations are done to pay back all the creditors amounts before giving the rests to the shareholders. However, it took a long and tedious process to complete this matter. Good examples are Enron, WorldCom and others.

b) Image Management Destroyed

Once the investors withdraw all the investments from the organizations, the amount of stock price will plump easily. It means danger because not much investors love to invest in a company with a low stock market. It shows that the company is not doing well. There might be an investor who buys those shares at low prices. However, investors these days tend not to purchase them easily once the share market plump. When they have think that this was not present in transparent and reliable ways, they will break out into the public and destroy the current image management of the organization. Hence, it helps to do nothing but create overwork for a company. It is because the image of an organization is hard to acquire or establish once it has been torn apart.

\section{Conclusions}

This article deeply recognized the factors that led to transparency in the financial statement. Transparency has been the only reliable way to have faith in the financial statements. Hence, it is not a simple matter that should be ignored or ruined by the organizations. As the organization is using the shareholder's investments, they must continue to carry such good faith in dealing with that money. When there is no transparency, the financial statements and its information are useless for the decision-making needs. It not only affects the shareholder, but also affects the organization's decision in the future.

This study finally managed to pull some relatedness between the dependent variables (financial statements) and its independent variables (accounting standards, corporate governance, internal controls, ethical practices and external controls). These variables have proven to enhance the reliability and transparency of the financial statements, thus increasing the informative needs, not only for the investors but the management to make a decision in the future. There is no need to research on which reasons to cutoff the financial statements into becoming informative financial statements. Now, these reasons are the ones that the companies should apply in the financial statements. In this case, CIMB Bank, who won the first in transparent and reliable financial statement, 2011 followed those variables tightly inside or outside the organization.

\section{Limitation and Further Studies}

There are several limitations that occurred in the research paper. Firstly, the number of management's respondents exceeds the auditor's and researcher's expectations. It was to accommodate the less number of auditor's respondents. Also, limitation time on the respondents and researchers were the main limitations for this paper. However, this article suggested several topics that might benefit the research in the future. Firstly, the study has developed a connection between its independent variables towards the financial statements. The best way to see the depth of transparency and reliability is the internal controls functions in the organization. Second, the researchers can include other variables that the researcher deducts from this study. Perhaps, it may trigger on other factors such as experience, study, equipment, knowledge and.

\section{References}

[1] Wood, F. and Sangster, A. (2008) What Is Accounting? In: Wood, F., Ed., Business Accounting 1, Prentice Hall, Italy, 3 .

[2] Wood, F. and Sangster, A. (2008) Accounting Policies. Prentice Hall, Italy.

[3] Bessire, D. (2005) Transparency: A Two-Way Mirror? International Journal of Social Economics, 32, 424-438. http://dx.doi.org/10.1108/03068290510591272

[4] IAS 8 (2005) Accounting Policies, Changes in Accounting Estimates and Errors. 
http://www.iasplus.com/en/standards/ias/ias8

[5] MASB (2006) Financial Reporting Standard 108. http://www.masb.org.my/index.php?option=com_content\&view=article\&id=79:frs108-pg4\&catid=6:masb-exclude-pri vate

[6] Damodaran, A. (2007) Information Transparency and Valuation: Can You Value What You Cannot See? Managerial Finance, 33, 877-892. http://dx.doi.org/10.1108/03074350710823836

[7] Berggren, E. and Bernshteyn, R. (2007) Organizational Transparency Drives Company Performance. Journal of Management Development, 26, 411-417. http://dx.doi.org/10.1108/02621710710748248

[8] Crumpton, M.A. (2011) The Value of Transparency. The Bottom Line: Managing Library Finances, 24, 125-128. http://dx.doi.org/10.1108/08880451111169188

[9] Jamshidinavid, B., Chavoshani, M. and Maroofi, F. (2012) The Investigation of Web-Based Accounting and Its Effects on Financial Report. Journal of Advanced Social Research, 2, 24-36.

[10] Hunton, J., Libby, R. and Mazza, C. (2004) Financial Reporting Transparency and Earnings Management. 1-36. http://dx.doi.org/10.2139/ssrn.501547

[11] Vrentzou, E. (2011) The Effects of International Financial Reporting Standards on the Notes of Auditors. Managerial Finance, 37, 334-346. http://dx.doi.org/10.1108/03074351111115296

[12] Abdolmohammadi, M.J. (2005) Intellectual Capital Disclosure and Market Capitalization. Journal of Intellectual Capital, 6, 397-416. http://dx.doi.org/10.1108/14691930510611139

[13] Liguori, M. and Steccolini, I. (2011) Accounting Change: Explaining the Outcomes, Interpreting. Accounting, Auditing \& Accountability Journal, 25, 27-70. http://dx.doi.org/10.1108/09513571211191743

[14] Weetman, P. (2001) Controlling the Standard-Setting Agenda: The Role of FRS 3. Accounting, Auditing \& Accountability Journal, 14, 85-109. http://dx.doi.org/10.1108/09513570110381088

[15] Sevin, S., Schroeder, R. and Bhamornsiri, S. (2007) Transparent Financial Disclosure and SFAS No. 142. Managerial Auditing Journal, 22, 674-687. http://dx.doi.org/10.1108/02686900710772582

[16] Cho, C.H., Freedman, M. and Patten, D.M. (2012) Corporate Disclosure of Environmental Capital Expenditures: A Test of Alternative Theories. Accounting, Auditing \& Accountability Journal, 25, 486-507. http://dx.doi.org/10.1108/09513571211209617

[17] Yakhou, M. and Dorweiler, V.P. (2004) Dual Reforms: Accounting and Corporate Governance. Managerial Auditing Journal, 19, 361-377. http://dx.doi.org/10.1108/02686900410524373

[18] Rezaee, Z. (2004) Restoring Public Trust in the Accounting Profession by Developing Anti-Fraud Education, Programs, and Auditing. Managerial Auditing Journal, 19, 134-148.

[19] Skaifea, H.A., Collins, D.W. and LaFond, R. (2006) The Effects of Corporate Governance on Firms' Credit Ratings. Journal of Accounting \& Economics, 42, 203-243. http://dx.doi.org/10.1016/j.jacceco.2006.02.003

[20] Atkinson, A.S. (2002) Ethics in Financial Reporting and the Corporate Communication Professional. Corporate Communications: An International Journal, 7, 212-218. http://dx.doi.org/10.1108/13563280210449796

[21] Adams, C.A. (2004) The Ethical, Social and Environmental Reporting-Performance Portrayal Gap. Accounting, Auditing \& Accountability Journal, 17, 731-757. http://dx.doi.org/10.1108/09513570410567791

[22] Stone, G. (2011) Let’s Talk: Adapting Accountants’ Communications to Small Business Managers’ Objectives and Preferences. Accounting, Auditing \& Accountability Journal, 24, 781-809. http://dx.doi.org/10.1108/09513571111155546

[23] Brennan, N.M. and Solomon, J. (2008) Corporate Governance, Accountability and Mechanisms of Accountability: An Overview. Accounting, Auditing \& Accountability Journal, 21, 885-906. http://dx.doi.org/10.1108/09513570810907401

[24] Grant, G.H. (2003) The Evolution of Corporate Governance and Its Impact on Modern Corporate America. Management Decision, 41, 923-934. http://dx.doi.org/10.1108/00251740310495045

[25] Rezaee, Z., Olibe, K.O. and Minmi, G. (2003) Improving Corporate Governance: The Role of Audit Committee Disclosures. Managerial Auditing Journal, 18, 530-537. http://dx.doi.org/10.1108/02686900310482669

[26] Spira, L.F. and Page, M. (2003) Risk Management: The Reinvention of Internal Control and the Changing Role of Internal Audit. Accounting, Auditing \& Accountability Journal, 16, 640-661. http://dx.doi.org/10.1108/09513570310492335

[27] Liou, F.-M. (2008) Fraudulent Financial Reporting Detection and Business Failure Prediction Models: A Comparison. Managerial Auditing Journal, 23, 650-662. http://dx.doi.org/10.1108/02686900810890625

[28] Kaminski, K.A., Wetzel, T.S. and Guan, L. (2004) Can Financial Ratios Detect Fraudulent Financial Reporting? Ma- 
nagerial Auditing Journal, 19, 15-28. http://dx.doi.org/10.1108/02686900410509802

[29] Hyland, M.M. and Verreault, D.A. (2003) Developing a Strategic Internal Audit-Human Resource Management Relationship: A Model and Survey. Managerial Auditing Journal, 18, 465-477. http://dx.doi.org/10.1108/02686900310482614

[30] Morrill, C. and Morrill, J. (2003) Internal Auditors and the External Audit: A Transaction Cost Perspective. Managerial Auditing Journal, 18, 490-504. http://dx.doi.org/10.1108/02686900310482632

[31] Braiotta Jr., L. and Zhou, J. (2006) An Exploratory Study of the Effects of the Sarbanes-Oxley Act, the SEC and United States Stock Exchange(s) Rules on Audit Committee Alignment. Managerial Auditing Journal, 21, 166-190. http://dx.doi.org/10.1108/02686900610639301

[32] Al-Ajmi, J. (2009) Audit Firm, Corporate Governance, and Audit Quality: Evidence from Bahrain. Advances in Accounting, Incorporating Advances in International Accounting, 25, 64-74. http://dx.doi.org/10.1016/j.adiac.2009.02.005

[33] Ortiz, E., Martínez, I. and Clavel, J.G. (2003) Ranking of Handicaps in International Financial Analysing. European Business Review, 15, 170-180. http://dx.doi.org/10.1108/09555340310474677

[34] Bierstaker, J.L. (2003) Auditor Recall and Evaluation of Internal Control Information: Does Task-Specific Knowledge Mitigate Part-List Interference? Managerial Auditing Journal, 18, 90-99. http://dx.doi.org/10.1108/02686900310455074

[35] Suwaidan, M.S. and Qasim, A. (2010) External Auditors' Reliance on Internal Auditors and Its Impact on Audit Fees: An Empirical Investigation. Managerial Auditing Journal, 25, 509-525. http://dx.doi.org/10.1108/02686901011054845

[36] Haron, H., Chambers, A., Ramsi, R. and Ismail, I. (2004) The Reliance of External Auditors on Internal Auditors. Managerial Auditing Journal, 19, 1148-1159. http://dx.doi.org/10.1108/02686900410562795

[37] Thurasingam, A.S. and Sivanandan, P. (2012) Generation Y's Perception towards Law and Ethics. Journal of Advanced Social Research, 2, 52-66.

[38] Makkawi, B. and Schick, A. (2003) Are Auditors Sensitive Enough to Fraud? Managerial Auditing Journal, 18, 591598. http://dx.doi.org/10.1108/02686900310482722

[39] Jackson, A. and Lapsley, I. (2003) The Diffusion of Accounting Practices in the New "Managerial" Public Sector. International Journal of Public Sector Management, 16, 359-372. http://dx.doi.org/10.1108/09513550310489304

[40] Shapeero, M., Koh, H.C. and Killough, L.N. (2003) Underreporting and Premature Sign-Off in Public Accounting. Managerial Auditing Journal, 18, 478-489. http://dx.doi.org/10.1108/02686900310482623 